\title{
Map and Track the Performance in Education for Sustainable Development across the European Union
}

\author{
Daniela Cristina Momete $^{1, *(D)}$ and Manuel Mihail Momete ${ }^{1,2}$ \\ 1 Faculty of Entrepreneurship, Business Engineering and Management, University Politehnica of Bucharest, \\ Splaiul Independentei, No. 313, S6, 060042 Bucharest, Romania; momete007@yahoo.com or \\ manuel.momete@stud.faima.upb.ro \\ 2 Quehenberger Logistics Rou SRL, Str. Transalkim, No. 3, 077061 Clinceni, Romania \\ * Correspondence: dana_momete@yahoo.com or daniela.momete@upb.ro
}

check for

updates

Citation: Momete, D.C.; Momete, M.M. Map and Track the Performance in Education for Sustainable Development across the European Union. Sustainability 2021, 13, 13185. https://doi.org/10.3390/su132313185

Academic Editors: María

Soledad Ramírez Montoya,

Ebba Ossiannilsson, Arturo Molina Gutiérrez and Jane-Frances Agbu

Received: 30 October 2021

Accepted: 26 November 2021

Published: 28 November 2021

Publisher's Note: MDPI stays neutral with regard to jurisdictional claims in published maps and institutional affiliations.

Copyright: (c) 2021 by the authors. Licensee MDPI, Basel, Switzerland. This article is an open access article distributed under the terms and conditions of the Creative Commons Attribution (CC BY) license (https:// creativecommons.org/licenses/by/ $4.0 /)$.

\begin{abstract}
The 17 sustainable development goals (SDG) established by 2030 Agenda cannot be achieved unless the learners are educated about sustainable development. Education for sustainable development (ESD) is a key component in preparing individuals to cope with sustainable challenges and paves the way towards a more sustainable aware society and life satisfaction. However, ESD is very complex as it depends on numerous factors and needs significant development all over the word. The paper aims to design an original and easy-to-apply framework which maps and tracks the actual performance in quality education across the European Union member states (EU27), focusing on SDG4-quality education from Agenda 30. The framework integrates three interventions-formal, non-formal, and essential education-and delivers a useful tool, a composite index, which maps and tracks the performance of the EU27 in the transition to ESD in a practical manner. The research categorizes four clusters of countries and tracks the Nordic countries of the EU27 among the high performers tier, allowing the identification of the best practices which can be spurred at European level. The findings of this paper may be used by educators, researchers, national and European authorities, and other stakeholders to monitor and accelerate progress in ESD, especially for low performers.
\end{abstract}

Keywords: education for sustainable development; quality education; European Union; well-being

\section{Introduction}

Education is the main driving force for development and the right to education was formulated by Article 26 of the Universal Declaration of Human Rights from 1948 [1,2]. Although this right was not legally binding, the United Nations (UN) Convention on the Rights of the Child from 1989 transformed it into a legally binding obligation for the states who have signed the treaty [3]. Moreover, the right to education is formulated by Article 14 of the Charter of Fundamental Rights of the European Union (EU) [4] which was later included in the Treaty of Lisbon [5] and since 2009 has been legally binding throughout the EU.

The 2030 Agenda for Sustainable Development adopted by the United Nations (UN) in 2015 [6] sets the scene for an ambitious development based on the transformation of existing economic, social, and environmental situations and aims to help reroute humankind on a sustainable track by 17 goals, containing 169 targets, which describe the main challenges for humans.

Education is formulated as a stand-alone goal (SDG4 - quality education), but it serves also as an enabler to achieve other SDGs. SDG4 seeks to "ensure inclusive and equitable quality education and promote lifelong learning opportunities for all by 2030" [7,8]. The 40th Session of the United Nations Educational, Scientific and Cultural Organization (UNESCO) Conference of 2019 adopted the framework for implementation of education for sustainable development (ESD) for 2030 which "encourages Governments to increase efforts to systemically integrate and institutionalize" EDS [9]. However, regardless of 
the fact that commitment to SDGs was declared by 193 countries, the Agenda 2030 is insufficiently implemented worldwide and produced no substantial change $[10,11]$.

The main outcome of an effective ESD will be the embrace of a sustainable lifestyle by all individuals. This may be achieved since ESD supports social integration, provides the required skills for a decarbonized and responsible resource-wise consumption, and helps involvement in the democratic life of individuals [12]. However, there are voices who still consider ESD a "luxury" [9,13], considering the survival challenges that face some parts of the world (extreme poverty, conflict zones, refugees), but the population in need is the first to receive an advantage from spurring ESD.

Education is in permanent contact with the society and represents a major contributor to people's happiness and perceived well-being, as it provides the main support for prosperity. In the member states of the EU (EU27), the data about well-being indicators show that the overall life satisfaction of people with tertiary, primary, and lower secondary education has a gap of 1 in EU27, with a maximum gap in Bulgaria-2.1-and a minimum gap in Denmark-0.1 (the life satisfaction gap is computed by subtracting average life satisfaction of people with primary and lower secondary education from the average life satisfaction of people with tertiary education, for people over 16 years) [14]. This shows that the people with tertiary education have an overall life satisfaction higher that those with primary and lower secondary education.

ESD is meant to develop knowledge and awareness of learners about sustainability challenges. Through learning, understanding, and applying into practice, the learners might become the agents of transformation of the society into a more sustainable one. ESD is also meant for lifelong learning and represents an essential key of quality education, leading in time to an authentic societal transformation [15]. An important factor for ESD is the quality of the teachers and many studies have tackled the topic of qualified teachers and of teacher effectiveness [16-18] The role of teachers is beyond the scope of this study which is based on the belief that every person is a learner, before and after formal education.

Several recent studies have tackled the progress towards several SDGs and have suggested ways to achieve these goals: SDG7-clean energy [19], SDG13-climate change [20], SDG17-public private partnership [21]. Regrettably, SDG4—quality education has been relatively ignored in the literature [22] and there is not a broad corpus of knowledge on this subject [23]. Measuring the progress of ESD is of critical importance, but it faces many challenges which have largely been recognised $[24,25]$. A composite index is a useful mix of many factors which are mathematically connected to result in a single number which reflects a large concept, and this can be applied also for ESD. Composite indexes and indicators have been used over time for many realms, including economy [26], society [27], environment [28], health [29], and innovation [30]. However, despite some progress on tackling SGDs, there are many research gaps which should be addressed and the need to define reliable indicators is one of them [31]. Therefore, this paper aims to ascertain the performance of EU27 in their transition to ESD by considering a straightforward practical framework. To this end, this paper introduces an original, easy to apply framework based on formal, non-formal, and essential education (FNE) which follows the learners at different ages, starting with young children, moving to youngsters, and finalizing with adults, considering key performance indicators (KPIs) which are both quantitative and qualitative in nature. FNE is a conceptual and practical framework which aims to map and track the performance in the transition to ESD across EU27 space using an original composite index - sustainable education index (SEI). The research is based on relevant, available, and recent evidence from EU27, referring both to quantity and quality of education.

The tracking of performance which ranks EU27 member states using SEI composite index allows a better understanding of the main education specifics necessary to develop ESD. Specifically, this research answers the following research questions (RQ):

$\mathrm{RQ}$ 1: Which are the best KPIs to be applied to practically characterize the performance of EU27 member states in their transition to ESD? 
RQ 2: Which is the best tool to evaluate and compare the performance of EU27 member states in their transition to ESD?

RQ3: Which are the best/worst performers in EU27 in their transition to ESD?

RQ4: What are the main recommendations that arise from application of SEI?

The rest of the paper is organized as follows: Section 2 elaborates on the methodology, Section 3 presents the results, and Section 4 discusses the findings of this research and their implications. Section 5 presents the concluding remarks, the main contributions and limitations of the study, and future lines of research.

\section{Methods}

The theoretical rationale of this research considers an original framework which takes into consideration three types of intervention lines, meant to portray the main outcomes on different ages: starting with young children, moving to youngsters, and finalizing with adults. Each intervention is designed on a set of two KPIs (see Figure 1):

1. F: Formal education: referring to the sides of formal education systems: early leavers from education and tertiary education.

2. N: Non-formal education: referring to life-long learning/adult learning and skills.

3. E: Essential education: referring to the basic knowledge of youngsters on PISA scale, meant to help them understand the importance of SDG.

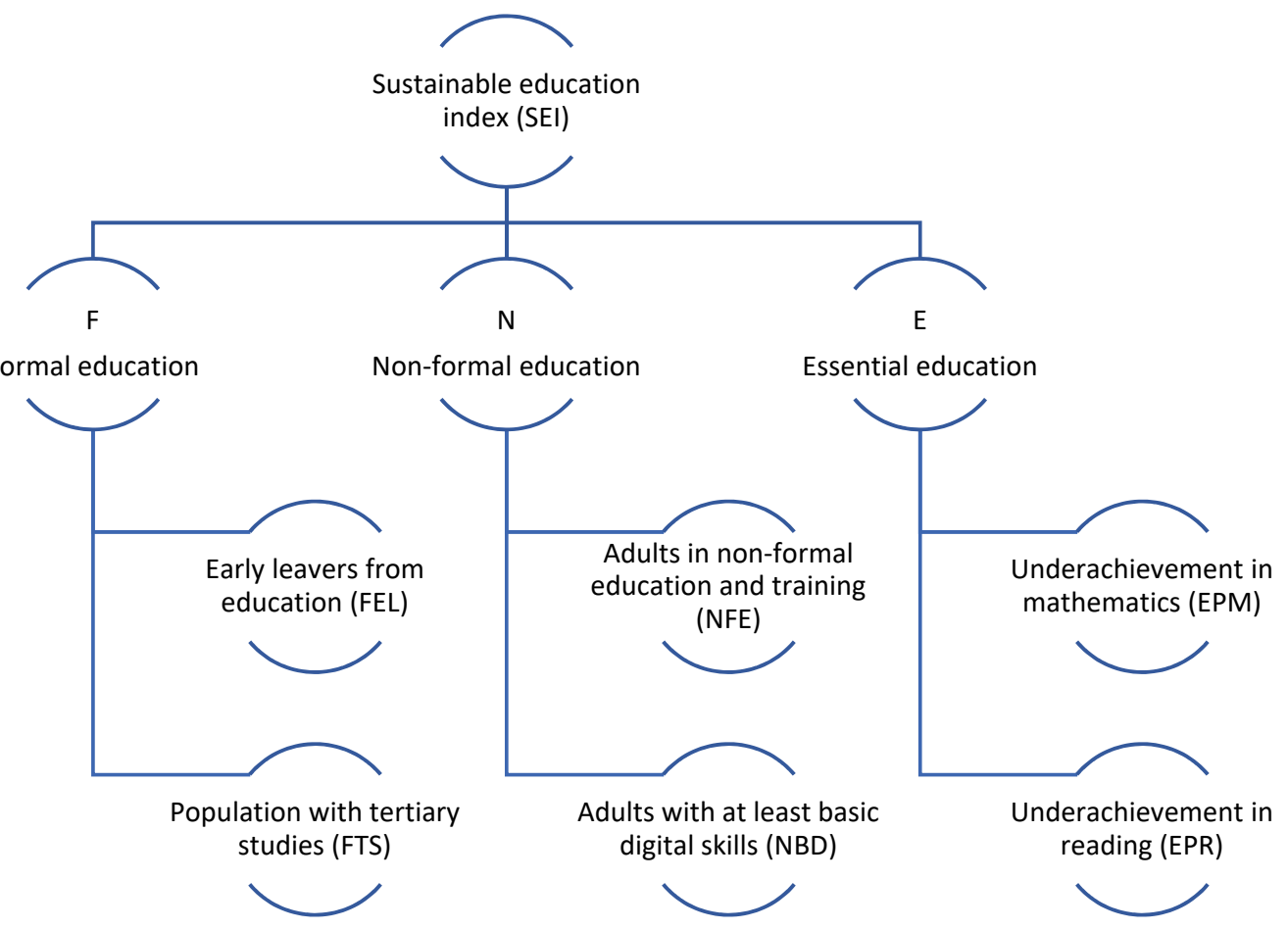

Figure 1. FNE conceptual framework. Source: authors' own elaboration.

The methodology involves a step-by-step approach, represented in Figure 2. The blueprint of this research follows three phases: (1) selection of the variables on each intervention line based on the FNE conceptual framework, (2) the correlation of the variables by data normalization and aggregation into SEI (3), and the testing of the SEI on EU27. 


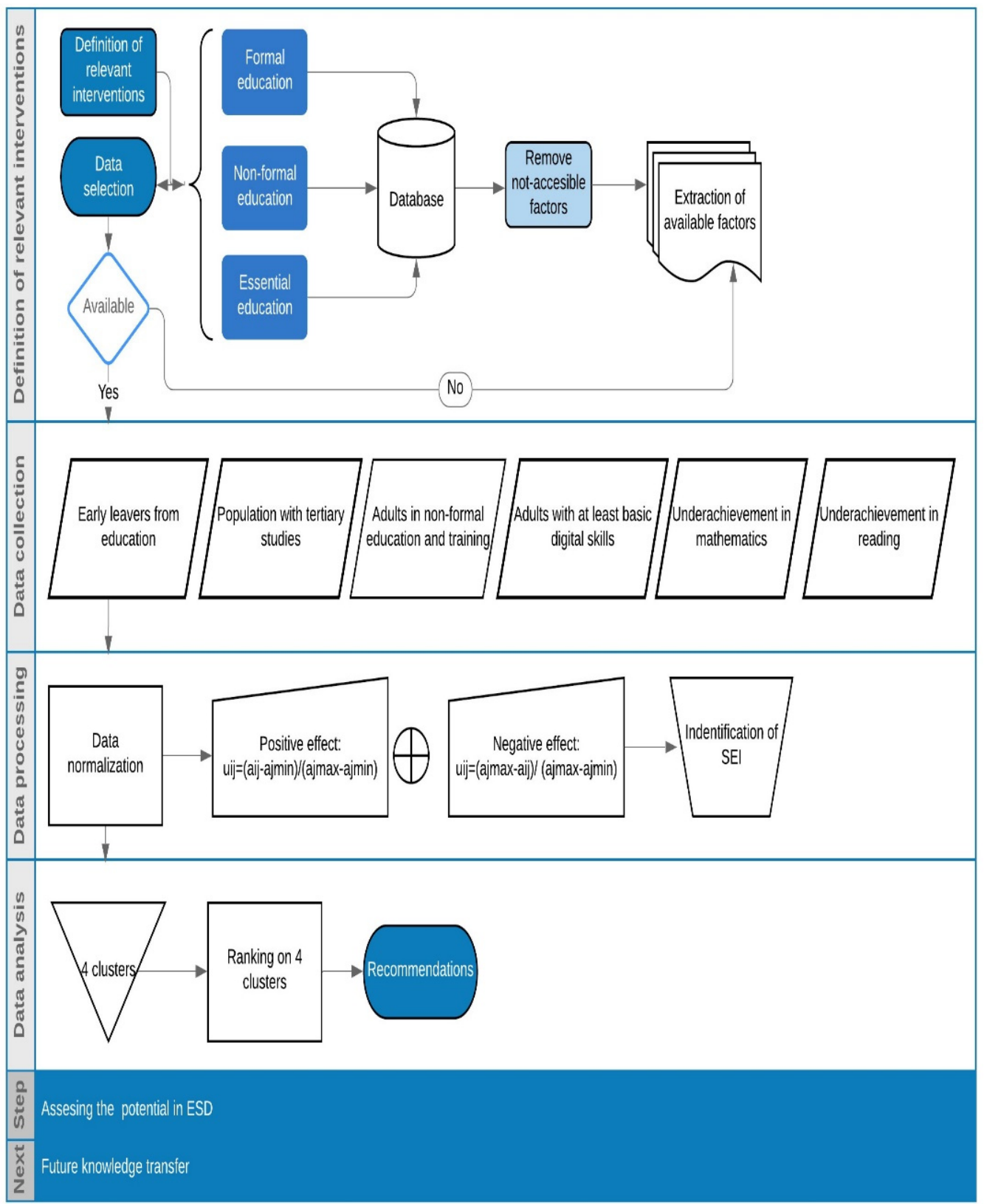

Figure 2. Methodology of the identification and application of sustainable education index (SEI). Source: authors' own elaboration using Lucidchart.

Phase 1-Definition of interventions on relevant KPI and data collection F: Formal education

- FEL: early leavers from education (descriptor: the share of the population aged 18-24 with, at most, lower secondary education) [32];

- $\quad$ FTS: population with tertiary studies (descriptor: share of the population aged 25-34 who have completed tertiary studies) [33].

$\mathrm{N}$ : Non-formal education

- NFE: adults in non-formal education and training (descriptor: the share of people aged 25-64 who stated that they received non-formal education and training) [34];

- NBD: adults with at least basic digital skills (descriptor: the share of people aged 18-74 who have at least basic digital skills) [35].

E: Essential education 
- EPM: underachievement in mathematics (descriptor: the share of 15-year-old students failing to reach basic skills level on the PISA scale for mathematics) [36];

- EPR: underachievement in reading (descriptor: the share of 15-year-old students failing to reach basic skills level on the PISA scale for reading) [37].

Phase 2-Data processing and calculation of SEI

Data normalization is done by applying the utilities theory, given the fact that the data are different in measures and scopes [38]. The negative or positive effect is represented by utilities which range from the best to the worst $\left(0<\mathrm{u}_{\mathrm{ij}}<1\right.$, where i refers to each indicator and $\mathrm{j}$ refers to each EU27 member state).

SEI is aggregated on the normalized series and the interventions are considered to have an equal importance for SEI (see Equations (1)-(4)).

$$
\begin{aligned}
& F=A V E R A G E(F E L+F T S) \\
& N=A V E R A G E(N F E+N B D \\
& E=A V E R A G E(E P M+E P R) \\
& S E I=A V E R A G E(F+N+E)
\end{aligned}
$$

Phase 3-Data analysis

Identification of rankings and 4 clusters of countries from EU27, depending on SEI, thought of in equal increments of 0.2 :

Cluster I: High performers: $0.7<$ SEI $<0.9$;

Cluster II: Moderate performers: $0.5<\mathrm{SEI}<0.7$;

Cluster III: Struggling performers: $0.3<\mathrm{SEI}<0.5$;

Cluster IV: Low performers: SEI $<0.3$.

\section{Results}

The business world employs KPIs to gather valuable information in order to track performance and to formulate judgements to obtain success [39]. This approach is tackled also by the present research which identifies relevant KPIs for each intervention line which are designed to depict the success of transition towards a genuine ESD for EU27.

The data considered for each intervention line are designed on relevant KPIs and available data which are retrieved from international reliable databases-Eurostat and Organisation for Economic Co-operation and Development—applicable for the last available year for all EU27 (see Table 1).

For FEL, the values place Croatia in the first place with only $2.20 \%$ early leavers from education and in the last place is Malta with $16.20 \%$ early leavers from education, far from the mean value for EU27 of $9.90 \%$. In our opinion, the countries above a threshold of $10 \%$ have major problems in addressing the early leavers from education and should focus on better retention policies and motivations for young learners (Cyprus, Hungary, Bulgaria, Italy, Romania, Spain, Malta).

For FTS, the best performer is Luxembourg with $60.60 \%$ population with tertiary studies, while the worst performer is Romania with only $24.90 \%$ population with tertiary studies, very far from the mean value EU27 of $40.50 \%$. In our opinion, the countries below a threshold of $40 \%$ should focus on offering more chances of development to the 25-34 young adults (Slovakia, Croatia, Germany, Bulgaria, Czechia, Hungary, Italy, Romania).

For NFE, the values place Sweden on top with $28.60 \%$ adults in non-formal education and training and in last place is Romania with only $1.00 \%$ adults in non-formal education and training, very remote from the mean value EU27 which is $9.20 \%$. In our opinion, the countries below a threshold of $10 \%$ have major problems in addressing this issue and should focus on better policies towards non-formal education of adults (Slovenia, Germany, Belgium, Italy Lithuania, Latvia, Czechia, Hungary, Cyprus, Greece, Poland, Croatia, Slovakia, Bulgaria, Romania). 
For NBD, the best performer is the Netherlands with $79.00 \%$ adults with at least basic digital skills, while the worst performer is Bulgaria with $29.00 \%$ adults with at least basic digital skills, far from the mean EU27 value of $56.00 \%$. In our opinion, the countries below a threshold of $50 \%$ have major problems in addressing this issue and should focus on offering digital training (Hungary, Cyprus, Poland, Latvia, Italy, Romania, Bulgaria).

Table 1. KPI for each intervention line for EU27 Adapted from [32-37].

\begin{tabular}{|c|c|c|c|c|c|c|}
\hline \multirow{2}{*}{ KPI } & \multicolumn{2}{|c|}{$\bar{F}$} & \multicolumn{2}{|c|}{$\mathbf{N}$} & \multicolumn{2}{|c|}{$\bar{E}$} \\
\hline & FEL (\%) & FTS (\%) & NFE (\%) & NBD (\%) & EPM (\%) & EPR (\%) \\
\hline Austria & 8.10 & 41.40 & 11.70 & 66.00 & 21.10 & 23.60 \\
\hline Belgium & 8.10 & 48.50 & 7.40 & 61.00 & 19.70 & 21.30 \\
\hline Bulgaria & 12.80 & 33.00 & 1.60 & 29.00 & 44.40 & 47.10 \\
\hline Croatia & 2.20 & 36.60 & 3.20 & 53.00 & 31.20 & 21.60 \\
\hline Cyprus & 11.50 & 57.80 & 4.70 & 45.00 & 36.90 & 43.70 \\
\hline Czechia & 7.60 & 33.00 & 5.50 & 62.00 & 20.40 & 20.70 \\
\hline Denmark & 9.30 & 47.10 & 20.00 & 70.00 & 14.60 & 16.00 \\
\hline Estonia & 7.50 & 43.10 & 17.10 & 62.00 & 10.20 & 11.10 \\
\hline Finland & 8.20 & 43.80 & 27.30 & 76.00 & 15.00 & 13.50 \\
\hline France & 8.00 & 49.40 & 13.00 & 57.00 & 21.30 & 20.90 \\
\hline Germany & 10.10 & 35.10 & 7.70 & 70.00 & 21.10 & 20.70 \\
\hline Greece & 3.80 & 43.70 & 4.10 & 51.00 & 35.80 & 30.50 \\
\hline Hungary & 12.10 & 30.70 & 5.10 & 49.00 & 25.60 & 25.30 \\
\hline Ireland & 5.00 & 58.40 & 11.00 & 53.00 & 15.70 & 11.80 \\
\hline Italy & 13.10 & 28.90 & 7.20 & 42.00 & 23.80 & 23.30 \\
\hline Latvia & 7.20 & 44.20 & 6.60 & 43.00 & 17.30 & 22.40 \\
\hline Lithuania & 5.60 & 56.20 & 7.20 & 56.00 & 25.60 & 24.40 \\
\hline Luxembourg & 8.20 & 60.60 & 16.30 & 65.00 & 27.20 & 29.30 \\
\hline Malta & 16.70 & 40.20 & 11.00 & 56.00 & 30.20 & 35.90 \\
\hline Netherlands & 7.00 & 52.30 & 18.80 & 79.00 & 15.80 & 24.10 \\
\hline Poland & 5.40 & 42.40 & 3.70 & 44.00 & 14.70 & 14.70 \\
\hline Portugal & 8.90 & 41.90 & 10.00 & 52.00 & 23.30 & 20.20 \\
\hline Romania & 15.60 & 24.90 & 1.00 & 31.00 & 46.60 & 40.80 \\
\hline Slovakia & 7.60 & 39.00 & 2.80 & 54.00 & 25.10 & 31.40 \\
\hline Slovenia & 4.10 & 45.40 & 8.40 & 55.00 & 16.40 & 17.90 \\
\hline Spain & 16.00 & 47.40 & 11.00 & 57.00 & 24.70 & 15.20 \\
\hline Sweden & 7.70 & 49.20 & 28.60 & 72.00 & 18.80 & 18.40 \\
\hline EU-27 & 9.90 & 40.50 & 9.20 & 56.00 & 22.90 & 22.50 \\
\hline
\end{tabular}

For EPM, the values place Estonia in first place with only $10.20 \%$ underachievers in mathematics and in last place is Romania with $46.60 \%$ underachievers in mathematics, very remote from mean EU27 value of $22.90 \%$. In our opinion, the countries above a threshold of $30 \%$ have major problems in addressing problems in understanding basic mathematics (level 2) and should focus on offering better education in mathematics (Malta, Croatia, Greece, Cyprus, Bulgaria, Romania).

For EPR, the best performer is Estonia with only $11.10 \%$ underachievers in reading while the worst performer is Bulgaria with $47.10 \%$ underachievers in reading, very far from 
the mean EU27 value of $22.50 \%$. In our opinion, the countries above a threshold of $30 \%$ have major problems in addressing problems in understanding basic readings (level 2) and should focus on offering better education in reading (Greece, Slovakia, Malta, Romania, Cyprus, Bulgaria).

However, Table 1 cannot offer an integrated view of all the considered interventions and this is achieved by the next phase of research. The considered values are normalised as presented by Phase 2 of the methodology and the results are presented in Table 2.

Table 2. The utilities for each line of intervention computed by Phase 2 of methodology.

\begin{tabular}{|c|c|c|c|c|c|c|}
\hline \multirow{2}{*}{ KPI } & \multicolumn{2}{|c|}{$\mathbf{F}$} & \multicolumn{2}{|c|}{$\mathbf{N}$} & \multicolumn{2}{|c|}{$\bar{E}$} \\
\hline & $\mathrm{U}_{\mathrm{FEL}}$ & $\mathrm{U}_{\mathrm{FTS}}$ & $\mathrm{U}_{\mathrm{NFE}}$ & $\mathrm{U}_{\mathrm{NBD}}$ & $\mathrm{U}_{\mathrm{EPM}}$ & $\mathrm{U}_{\mathrm{EPR}}$ \\
\hline Austria & 0.59 & 0.46 & 0.39 & 0.74 & 0.70 & 0.65 \\
\hline Belgium & 0.59 & 0.66 & 0.23 & 0.64 & 0.74 & 0.72 \\
\hline Bulgaria & 0.27 & 0.23 & 0.02 & 0.00 & 0.06 & 0.00 \\
\hline Croatia & 1.00 & 0.33 & 0.08 & 0.48 & 0.42 & 0.71 \\
\hline Cyprus & 0.36 & 0.92 & 0.13 & 0.32 & 0.27 & 0.09 \\
\hline Czechia & 0.63 & 0.23 & 0.16 & 0.66 & 0.72 & 0.73 \\
\hline Denmark & 0.51 & 0.62 & 0.69 & 0.82 & 0.88 & 0.86 \\
\hline Estonia & 0.63 & 0.51 & 0.58 & 0.66 & 1.00 & 1.00 \\
\hline Finland & 0.59 & 0.53 & 0.95 & 0.94 & 0.87 & 0.93 \\
\hline France & 0.60 & 0.69 & 0.43 & 0.56 & 0.70 & 0.73 \\
\hline Germany & 0.46 & 0.29 & 0.24 & 0.82 & 0.70 & 0.73 \\
\hline Greece & 0.89 & 0.53 & 0.11 & 0.44 & 0.30 & 0.46 \\
\hline Hungary & 0.32 & 0.16 & 0.15 & 0.40 & 0.58 & 0.61 \\
\hline Ireland & 0.81 & 0.94 & 0.36 & 0.48 & 0.85 & 0.98 \\
\hline Italy & 0.25 & 0.11 & 0.22 & 0.26 & 0.63 & 0.66 \\
\hline Latvia & 0.66 & 0.54 & 0.20 & 0.28 & 0.80 & 0.69 \\
\hline Lithuania & 0.77 & 0.88 & 0.22 & 0.54 & 0.58 & 0.63 \\
\hline Luxembourg & 0.59 & 1.00 & 0.55 & 0.72 & 0.53 & 0.49 \\
\hline Malta & 0.00 & 0.43 & 0.36 & 0.54 & 0.45 & 0.31 \\
\hline Netherlands & 0.67 & 0.77 & 0.64 & 1.00 & 0.85 & 0.64 \\
\hline Poland & 0.78 & 0.49 & 0.10 & 0.30 & 0.88 & 0.90 \\
\hline Portugal & 0.54 & 0.48 & 0.33 & 0.46 & 0.64 & 0.75 \\
\hline Romania & 0.08 & 0.00 & 0.00 & 0.04 & 0.00 & 0.18 \\
\hline Slovakia & 0.63 & 0.39 & 0.07 & 0.50 & 0.59 & 0.44 \\
\hline Slovenia & 0.87 & 0.57 & 0.27 & 0.52 & 0.83 & 0.81 \\
\hline Spain & 0.05 & 0.63 & 0.36 & 0.56 & 0.60 & 0.89 \\
\hline Sweden & 0.62 & 0.68 & 1.00 & 0.86 & 0.76 & 0.80 \\
\hline
\end{tabular}

Source: authors' own elaboration.

The data from Table 2 allow for the identification of SEI by applying Equations (1)-(4) and the results are given in Table 3, which ranks from the best to the worst the performers of EU27, on four clusters. The actual values of SEI are represented in Figure 3 which shows the EU27 map, ranging from the best (dark blue) to the worst (light blue). 
Table 3. Sustainable education index (SEI) and clusters. (green—cluster I, light blue—cluster 2, light yellor-cluster 3 and orange-cluster 4).

\begin{tabular}{|c|c|c|c|c|c|}
\hline Rank. & Country & $\begin{array}{l}\text { Sustainable } \\
\text { Education } \\
\text { Index (SEI) }\end{array}$ & Value & Clusters & SEI Values (0-1) \\
\hline 1 & Finland & 0.802 & \multirow{6}{*}{$0.7<\mathrm{SEI}<0.9$} & \multirow{6}{*}{$\begin{array}{l}\text { Cluster I: } \\
\text { High performers }\end{array}$} & \\
\hline 2 & Sweden & 0.787 & & & \\
\hline 3 & Netherlands & 0.761 & & & \\
\hline 4 & Ireland & 0.736 & & & \\
\hline 5 & Estonia & 0.731 & & & \\
\hline 6 & Denmark & 0.731 & & & \\
\hline 7 & Luxembourg & 0.648 & \multirow{13}{*}{$0.5<\mathrm{SEI}<0.7$} & \multirow{13}{*}{$\begin{array}{l}\text { Cluster II: } \\
\text { Moderate } \\
\text { performers }\end{array}$} & \\
\hline 8 & Slovenia & 0.645 & & & \\
\hline 9 & France & 0.617 & & & \\
\hline 10 & Lithuania & 0.602 & & & E \\
\hline 11 & Belgium & 0.597 & & & \\
\hline 12 & Austria & 0.589 & & & \\
\hline 13 & Poland & 0.574 & & & \\
\hline 14 & Germany & 0.540 & & & \\
\hline 15 & Portugal & 0.531 & & & \\
\hline 16 & Latvia & 0.528 & & & \\
\hline 17 & Czechia & 0.522 & & & \\
\hline 18 & Spain & 0.515 & & & \\
\hline 19 & Croatia & 0.503 & & & \\
\hline 20 & Greece & 0.454 & \multirow{6}{*}{$0.3<\mathrm{SEI}<0.5$} & \multirow{6}{*}{$\begin{array}{l}\text { Cluster III: } \\
\text { Struggling } \\
\text { performers }\end{array}$} & \\
\hline 21 & Slovakia & 0.436 & & & \\
\hline 22 & Hungary & 0.368 & & & \\
\hline 23 & Italy & 0.355 & & & \\
\hline 24 & Cyprus & 0.349 & & & \\
\hline 25 & Malta & 0.349 & & & \\
\hline 26 & Bulgaria & 0.096 & \multirow{2}{*}{$0<\mathrm{SEI}<0.3$} & \multirow{2}{*}{$\begin{array}{c}\text { Cluster IV: } \\
\text { Low performers }\end{array}$} & \\
\hline 27 & Romania & 0.048 & & & \\
\hline
\end{tabular}


Sustainable education index (EU27)

0.048 0.802

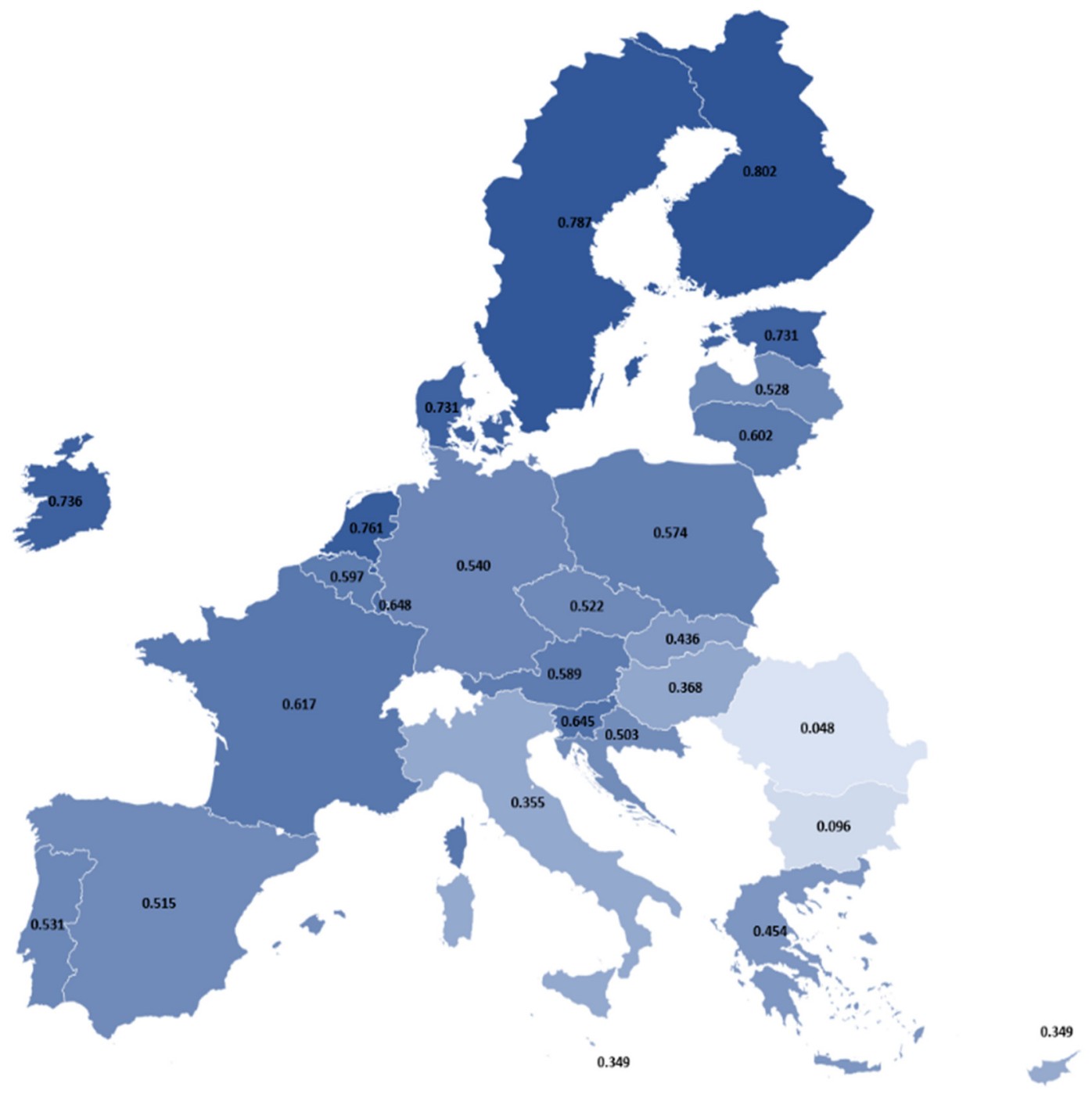

Figure 3. Choropleth map of EU27 for sustainable education index. Source: authors' own elaboration.

\section{Discussion}

The commitment towards ESD means decreasing differences in learning outcomes for all ages. The conviction of the authors is that only what can be measured gets counted and counts for developing a strong ESD. Therefore, a framework with appropriate metrics is considered for measuring the transition of EU27 towards an effective EDS. The selection of KPIs belonging to each line of intervention aims to encapsulate the quantity, but also the quality, and by this inclusion our concept differentiates from other conceptual models. The formal education is a quantity-based line of intervention and takes into consideration both ends of the education system: the ones with the least education (early leavers from education) and the graduates of tertiary studies. The non-formal education is a dual line of intervention, having a quantity based KPI (adults in non-formal education and training) and a quality based on KPI, referring to the actual basic digital skills. The essential education is a quality-based line of intervention, referring to the actual functional knowledge in mathematics and reading of the 15-year-olds. The digital skills are included separately, as today education also means digitalisation and this paves the way for the improved accessibility to education for all ages.

The judgement on individual results of each member state of the EU shows a complex, mixed picture of ESD. While the best and worst performers for each of the six KPI are 
easily grasped, the SEI index allows the identification of the best/worst overall performer. For example, while Estonia was first for two individual KPIs, the best overall performer was Finland, which was not best for any of the individual KPIs. The SEI index allows the splitting of countries into four clusters:

Cluster I: High performers $(0.7<\mathrm{SEI}<0.9)$ : six countries which employed meaningful measures dedicated to ESD. In this tier are included the countries belonging to the Northern EU27 (Finland, Sweden, Netherlands, Ireland, Estonia, Denmark).

Cluster II: Moderate performers $(0.5<\mathrm{SEI}<0.7)$ : 13 countries which applied necessary, but insufficient, measures to boost EDS. This is the cluster which includes the largest number of countries, showing that there is a great potential in spreading EDS in EU27 (Luxembourg, Slovenia, France, Lithuania, Belgium, Austria, Poland, Germany, Portugal, Latvia, Czechia, Spain, Croatia).

Cluster III: Struggling performers $(0.3<\mathrm{SEI}<0.5)$ : six countries which employed some measures, but neither necessary nor sufficient, for the development of ESD (Greece, Slovakia, Hungary, Italy, Cyprus, Malta).

Cluster IV: Low performers $(0.3<\mathrm{SEI}<0)$ : two countries which applied no essential measures to foster ESD (Bulgaria and Romania). This is the cluster which includes only two countries, and they may recuperate by starting to address at least one of the KPIs. Romania and Bulgaria are the sole countries which are under the individual thresholds for all the KPIs considered for ESD.

Our results are similar to other studies, pointing out the performance of education in the Northern EU27 and the striving of the Southern and Eastern part to achieve better results $[40,41]$. Our results are in line with other studies [42,43] which have shown that in Romania many indicators related to education are suboptimal and people do not have much knowledge about why sustainable development should guide their lifestyle. At the same time, in Bulgaria the commitment towards SDGs has not been systemic and has supposed only sporadic involvement of Non-Governmental Organizations (NGOs) on specific, limited issues [44]. The low performers should address these problems and must start learning from the best, meaning applying the methods which proved their efficiency in the Nordic countries, but thought of in the context of the realities of the target population, with a keen eye on the national characteristics. The best policies to be first tackled by the low performers are regarding a completely free education system, from primary to tertiary education, including also a free hot meal during school time. In Finland and Sweden there are also private schools, but the costs of private schools are fully subsidized regarding the tax and employ free hot meals during school time [45]. Furthermore, the inclusive education for all students, including of those with special needs, proved to be a factor of success which must be employed also by low performers.

The construction of the KPIs of this research aimed to encapsulate the quantity, but also the quality, mainly revealed by results obtained at PISA testing. An initiative that results from the present research is the need to assess the relevancy of tertiary education. If for 15-year-olds there are PISA tests, considered to be "the world's most comprehensive and reliable international comparison" for pupils [46], for graduates of the tertiary education there is no test to quantify the graduates' actual specific knowledge and understanding and this must also include responsibility for sustainable development. Therefore, our belief is that the universities must be more involved in the active evaluation of competencies of graduates through a national/European professional licence/professional exam. Presently, there are some initiatives from professionals, like the National Society of Professional Engineers from United States [47] or the European Logistics Association [48], which implement a certification for practice engineering and logisticians respectively, but they lack the sustainability component.

Globally, the EU27 picture is promising towards the transition towards ESD, 70\% of the countries being on the right track, but many challenges remain, especially for the rest of the $30 \%$. This means, especially for low performers, a need for collaboration of all the stakeholders from education to improve the transition towards ESD. Learning from 
international evidence is the best way to cope with present challenges [49]. Although the education systems are different across EU27, the most important recommendations are coming from the best performers considered by the FNE framework, which must be swiftly spurred at European level:

- Expand the compulsory education for both ends of the education system. Half of EU27 countries start the compulsory education at the age of 6 and finalize it at the age of 16 [40];

- Consider a completely free education system, from primary to tertiary education, including also a free/subsidised hot meal during school time. This already happens in Finland and Sweden, as previously mentioned [45];

- Promote policies for the inclusive education for all learners, including those with special needs;

- Introduce training obligations at the end of the compulsory education until the age of 18 (unless the pupil does not continue the studies: tertiary education, vocational training). For instance, in France, this has been introduced starting with 2020 [50];

- $\quad$ Provide ICT education for all ages for digital skills development;

- Measure learning earlier to identify gaps in essential education and act on them sooner (PISA testing is aimed at 15-year-olds);

- Involve higher education institutions in the active evaluation of competencies of graduates through a national/European professional licence/professional exam which must include responsibilities for sustainable development;

- Allow a holistic skill development by flexible curricula focused on student learning.

- Foster responsibility of learners by promoting teaching based on sustainable development core issues;

- $\quad$ Provide more funding for education and restrain from budget cuts, as they are still happening for the countries belonging to Cluster 4 .

All the RQs identified within the introduction have a proper answer and the results reveal that the EU27 presents a diverse and complex picture of ESD, in terms of SDG4. The results of our work show that the EU27 picture is promising towards the transition towards ESD (in terms of SDG4 targets), 70\% of the countries being on the right track. However, there are still many challenges for all countries, especially for the rest of the $30 \%$.

In line with our findings, the EU27 member states must develop a national indicator to monitor the national progress. They must also consider the inclusion of all the initiatives and outcomes of ESD when they evaluate the progress on ESD. The collection of data at the national/international level should be strengthened, diversified, and rapidly available in order to properly analyse the feedback on student learning.

The diversity of national education systems within EU27 requires a common framework of classification. Therefore, a unified holistic framework should be developed for countries' monitoring, which will take into consideration a set of comparable outcomes, but more technical data is needed to construct such a complex framework.

\section{Conclusions}

The sustainable development main 5 Ps (People, Planet, Prosperity, Peace, and Partnerships) contained within the SDGs require a new vision on education. ESD is an authentic cross-cutting tool for all SDGs and represents the key for the transition towards a more sustainable future. On the road towards a sustainable destination, our work has contributed on several tracks:

- Introducing FNE conceptual framework involving the selection of the most appropriate KPIs for ESD—inclusive and equitable quality education;

- Calculating a composite index meant to reflect the ranking of each country: SEI;

- $\quad$ Application of the FNE framework to EU27;

- Identification of clusters of countries depending on SEI and recommendations, especially for low performers. 
The limitations of this work are mainly referring to the identification of relevant, fully accessible, and updated data. The data referring to education for ESD are difficult to grasp, as some countries do not systematically collect data, or the data considered are less formalized and diffuse [51]. Moreover, data gaps and data lags in official statistics related to education make the identification of suitable and relevant data very difficult [52]. Nevertheless, the present research included a suitable number of relevant KPIs to make the study meaningful for educators, researchers, national and European authorities, and other stakeholders. Moreover, the SEI index, although it is not perfect, is relevant as it meets all the features of relevancy [53]: it is specific, measurable, based on available data, practical, well-grounded scientifically, being based on normalization and aggregation of data, and impartial.

The political implications of this research place a lens on the need of a response of each member state, as essential efforts are needed from the national authorities. The implementation of SDGs requires major investments and when the focus is on SDG4, this investment means a public investment in human capital. Education is that which builds human capital; therefore, it must receive more attention, especially when it is majorly affected by the actual COVID pandemic which already eroded the progress in SDG4 all over the world [52].

The practical implications of our work emphasise that the EU27 needs a multistakeholder engagement at local, national, and European level and factual initiatives to implement SGD4 and all the other SGDs. The promise of 2030 Agenda "leave no one behind" must be transferred from paper to immediate and continuous action and this requires mainly political will. This involves a change in policy and financial support to transform the learning environments with actions on educators, learners, and communities.

There are still research gaps to be filled and a more in-depth analysis by the actual providers of education, schools, and academic circles, should be ascertained, as the publications on SGD4 are mainly authored by international bodies [54].

This research opens the way to an authentic journey to quality education which will result, we hope, in a further transfer of knowledge that will lead to better learning environments. This research has not included the effects of COVID pandemic, but the deadly disease already added and continues to add supplemental strains to all education systems. This line of research opens the path for future research based on an iterative model of improvement of ESD in EU27, with a focus set on transformative pedagogies which will also include the lingering lessons learned from COVID 19.

Author Contributions: Conceptualization, D.C.M. and M.M.M.; methodology, D.C.M. and M.M.M.; validation, D.C.M. and M.M.M.; investigation, D.C.M. and M.M.M.; writing—original draft preparation, D.C.M. and M.M.M.; writing-review and editing, D.C.M. and M.M.M. All authors have read and agreed to the published version of the manuscript.

Funding: The APC was funded by University POLITEHNICA of Bucharest, Romania, through the project "Engineer in Europe" - registered at the Romanian Ministry of Education under No.140/GP/ 19.04.2021, from the fund for financing special situations.

Institutional Review Board Statement: Not applicable.

Informed Consent Statement: Not applicable.

Data Availability Statement: Not applicable.

Conflicts of Interest: The authors declare no conflict of interest.

\section{References}

1. Moriarty, K. Achieving SDG4 Through a Human Rights Based Approach to Education. World Development Report 2018 Background Paper; World Bank: Washington, DC, USA, 2017; p. 6. Available online: https:/ /openknowledge.worldbank.org/handle/10986/28869 (accessed on 20 November 2021).

2. United Nations (UN). Universal Declaration of Human Rights. 1948. Available online: http://www.un.org/en/universaldeclaration-human-rights/ (accessed on 19 November 2021). 
3. United Nations (UN). Convention of the Rights of the Child. 1989. Available online: https://www.ohchr.org/en/ professionalinterest/pages/crc.aspx (accessed on 19 November 2021).

4. European Commission. Charter of Fundamental Rights of the European Union, Official Journal of the European Communities O.J. 2000/C 364/01. 18 December 2000. Available online: https:/ / www.europarl.europa.eu/charter/pdf/text_en.pdf (accessed on 20 November 2021).

5. Treaty of Lisbon Amending the Treaty on European Union and the Treaty Establishing the European Community, 13 December 2007. 2007/C 306/01. Available online: http:/ / eur-lex.europa.eu/ (accessed on 20 November 2021).

6. United Nations (UN). Transforming Our World: The 2030 Agenda for Sustainable Development. 2015. Available online: https: //www.un.org/ga/search/view_doc.asp?symbol=A/RES/70/1\&Lang=E (accessed on 12 October 2021).

7. SDG4-High-Level Steering Committee. Sustainable Development Goal 4 (SDG 4). 2021. Available online: https://sdg4 education2030.org/the-goal (accessed on 15 October 2021).

8. Rieckmann, M. Education for Sustainable Development Goals: Learning Objectives; UNESCO Publishing: Paris, France, 2017 ; p. 21.

9. United Nations Educational, Scientific and Cultural Organization (UNESCO). Education for Sustainable Development-A Roadmap; UNESCO Publishing: Paris, France, 2020; p. 64.

10. World Bank. World Development Report 2021: Data for Better Lives; World Bank: Washington, DC, USA, 2021; pp. 64-66. [CrossRef]

11. Saye, Y.; Moriarty, K. Chapter 9: SDG 4 and the 'Education Quality Turn' Prospects, Possibilities, and Problems in Grading Goal Four; Wulf, A., Ed.; Koninklijke Brill NV: Leiden, The Netherlands, 2020; pp. 194-213. [CrossRef]

12. Prime Minister's Office. Voluntary National Review 2020 Finland Report on The Implementation of the 2030 Agenda for Sustainable Development; Prime Minister's Office: Helsinki, Finland, 2020; pp. 45-51.

13. Rashid, L. Entrepreneurship Education and Sustainable Development Goals: A literature Review and a Closer Look at Fragile States and Technology-Enabled Approaches. Sustainability 2019, 11, 5343. [CrossRef]

14. Eurostat. Eurostat On-Line Database, Average Rating of Satisfaction by Domain, Sex, Age and Educational Attainment Level, Code: ILC_PW01. Available online: https:/ / ec.europa.eu/eurostat/databrowser/view/ILC_PW01_custom_1173990/ bookmark/table?lang=en\&bookmarkId=414b376e-7b8b-4736-8a07-210874a32c6d (accessed on 20 October 2021).

15. Müller, U.; Hancock, D.R.; Stricker, T.; Wang, C. Implementing ESD in Schools: Perspectives of Principals in Germany, Macau, and the USA. Sustainability 2021, 13, 9823. [CrossRef]

16. Ingersoll, R. Teacher Turnover and Teacher Shortages: An Organizational Analysis. Am. Educ. Res. J. 2001, 38, 499. [CrossRef]

17. Stronge, J.; Ward, T.; Grant, L. What Makes Good Teachers Good? A Cross-Case Analysis of the Connection Between Teacher Effectiveness and Student Achievement. J. Teach. Educ. 2011, 62, 339. [CrossRef]

18. Kraft, M.; Gilmour, A. Revisiting the widget effect: Teacher evaluation reforms and the distribution of teacher effectiveness. Educ. Res. 2017, 46, 234-249. [CrossRef]

19. Anwar, A.; Siddique, M.; Dogan, E.; Sharif, A. The moderating role of renewable and non-renewable energy in environmentincome nexus for ASEAN countries: Evidence from method of moments quantile regression. Renew. Energy 2021, 164, $956-967$. [CrossRef]

20. Jun, W.; Mughal, N.; Zhao, J.; Shabbir, M.S.; Niedbała, G.; Jain, V.; Anwar, A. Does globalization matter for environmental degradation? Nexus among energy consumption, economic growth, and carbon dioxide emission. Energy Policy 2021, $153,112230$.

21. Umar, M.; Ji, X.; Mirza, N.; Rahat, B. The impact of resource curse on banking efficiency: Evidence from twelve oil producing countries. Resour. Policy 2021, 72, 102080. [CrossRef]

22. Wang, X.; Li, G.; Malik, S.; Anwar, A. Impact of COVID-19 on achieving the goal of sustainable development: E-learning and educational productivity. Econ. Res. Ekon. Istraživanja 2021, 34, 1-17. [CrossRef]

23. González García, E.; Colomo Magaña, E.; Cívico Ariza, A. Quality Education as a Sustainable Development Goal in the Context of 2030 Agenda: Bibliometric Approach. Sustainability 2020, 12, 5884. [CrossRef]

24. Leicht, A.; Heiss, J.; Byun, W.J. (Eds.) Issues and Trends in Education for Sustainable Development; UNESCO: Paris, France, $2018 ;$ p. 14.

25. Hanushek, E.; Woessmann, L. A quantitative look at the economic impact of the European Union's educational goals. Educ. Econ. 2020, 28, 225-244. [CrossRef]

26. Organisation for Economic Co-operation and Development (OECD). Monthly Economic Indicators-Composite Leading Indicators. 2021. Available online: https:/ / data.oecd.org/leadind/composite-leading-indicator-cli.htm (accessed on 30 October 2021). [CrossRef]

27. Jahan, S. Human Development Report 2015: Work for Human Development; United Nations Development Program (UNDP): New York, NY, USA, 2015; p. 22.

28. Wendling, Z.A.; Emerson, J.W.; de Sherbinin, A.; Esty, D.C. 2020 Environmental Performance Index; Yale Center for Environmental Law \& Policy: New Haven, CT, USA, 2020.

29. Momete, D.C. Building a Sustainable Healthcare Model: A Cross-Country Analysis. Sustainability 2016, 8, 836. [CrossRef]

30. European Commission. European and Regional Innovation Scoreboards 2021. Available online: https://ec.europa.eu/researchand-innovation/en/statistics/performance-indicators/european-innovation-scoreboard/eis (accessed on 23 October 2021).

31. Filho, W.; Frankenberger, F.; Salvia, A.; Azeiteiro, U.; Alves, F.; Castro, P.; Will, M.; Platje, J.; Orlovic Lovren, V.; Brandli, L.; et al. A framework for the implementation of the Sustainable Development Goals in university programmes. J. Clean Prod. 2021, 299, 126915. [CrossRef] 
32. Eurostat. Eurostat On-Line Database, Early Leavers from Education and Training. Available online: https://appsso.eurostat.ec. europa.eu/nui/show.do?dataset=edat_lfse_14\&lang=en (accessed on 22 September 2021).

33. Eurostat. Eurostat On-Line Database, Tertiary Educational Attainment by Sex. Available online: https://ec.europa.eu/eurostat/ databrowser/view/sdg_04_20/default/table?lang=en (accessed on 22 September 2021).

34. Eurostat. Eurostat On-Line Database, Participation Rate in Education and Training. Available online: https://appsso.eurostat.ec europa.eu/nui/show.do?dataset=trng_lfse_01\&lang=en (accessed on 22 September 2021).

35. Eurostat. Eurostat On-Line Database, Individuals' Level of Digital Skills. Available online: https:/ /appsso.eurostat.ec.europa.eu/ nui/show.do?dataset=isoc_sk_dskl_i\&lang=en (accessed on 22 September 2021).

36. Organisation for Economic Co-operation and Development (OECD). Online Database, Mathematics Performance. Available online: https:/ / data.oecd.org/pisa/mathematics-performance-pisa.htm (accessed on 2 October 2021).

37. Organisation for Economic Co-operation and Development (OECD). Online Database, Reading Performance. Available online: https:/ / data.oecd.org/pisa/reading-performance-pisa.htm\#indicator-chart (accessed on 2 October 2021).

38. Momete, D.C. Analysis of the Potential of Clean Energy Deployment in the European Union. IEEE Access 2018, 6, 54811-54822. [CrossRef]

39. Van Gorp, J. Using key performance indicators to manage energy costs. Strateg. Plan. Energy Environ. 2005, 25, 9-25. [CrossRef]

40. Rakocevic, R.; Fournier, Y. (Eds.) Education in Europe: Key Figures 2020, Directorate of Evaluation, Forecasting and Performance Monitoring; Minister of National Education: Paris, France, 2020. Available online: https:/ / www.education.gouv.fr/educationeurope-key-figures-2020-306484 (accessed on 18 November 2021).

41. Herrera-Sosa, K.; Hoftijzer, M.; Gortazar, L.; Ruiz, M. Education in the EU: Diverging Learning Opportunities? Background Paper. World Bank, 2018. Available online: https:/ / pubdocs.worldbank.org/en/180421529688002726/EU-GU-Skill-Supply-final-5-30-2 018.pdf (accessed on 18 November 2021).

42. Firoiu, D.; Ionescu, G.H.; Băndoi, A.; Florea, N.M.; Jianu, E. Achieving Sustainable Development Goals (SDG): Implementation of the 2030 Agenda in Romania. Sustainability 2019, 11, 2156. [CrossRef]

43. Roszkowska, E.; Filipowicz-Chomko, M. Measuring sustainable development in the education area using multi-criteria methods: A case study. Cent. Eur. J. Oper. Res. 2020, 28, 1219-1241. [CrossRef]

44. Bulgarian Gender Research Foundation (BGRF) \& Bulgarian Social Watch. Implementing the SDGs-From Discussions to Strategies and Reforms. 2017. Available online: https://www.socialwatch.org/node/17733 (accessed on 23 October 2021).

45. Lundahal, L. Equality, inclusion and marketization of Nordic education: Introductory notes. Res. Comp. Int. Educ. 2016, 11, 3-12. [CrossRef]

46. Organisation for Economic Co-operation and Development (OECD)—Education International. Principles for an Effectiveand Equitable Educational Recovery; OECD Publishing: Paris, France, 2020; p. 7.

47. National Society of Professional Engineers, (NSPE). Available online: https:/ /www.nspe.org/ (accessed on 28 October 2021).

48. European Logistics Association (ELA). Available online: https:/ / www.elalog.eu/ (accessed on 28 October 2021).

49. Schleicher, A. PISA 2018-Insights and Interpretations; OECD Publishing: Paris, France, 2019; p. 55.

50. Ministry of National Education, of Youth and Sport-Ministère de l'Education Nationale, de la Jeunesse et des Sports, Journal Officiel De La République Française, France, Law—Decree 978 of 5 August 2020). Available online: https: / / www.legifrance.gouv. $\mathrm{fr} /$ jorf/id/JORFTEXT000042211037?r=wex5cIfpyO (accessed on 20 November 2021).

51. United Nations Educational, Scientific and Cultural Organization (UNESCO). Shaping the Future We Want-UN Decade of Education for Sustainable Development; UNESCO: Paris, France, 2014; p. 72.

52. Sachs, J.; Kroll, C.; Lafortune, G.; Fuller, G.; Woelm, F. Sustainable Development Report 2021; University Printing House: Cambridge, UK, 2021; pp. 9-13.

53. Bohringer, C.; Jochem, P. Measuring the immeasurable: A survey of sustainability indices. Ecol. Econ. 2007, 63, 1-8. [CrossRef]

54. Prieto-Jiménez, E.; López-Catalán, L.; López-Catalán, B.; Domínguez-Fernández, G. Sustainable Development Goals and Education: A Bibliometric Mapping Analysis. Sustainability 2021, 13, 2126. [CrossRef] 